\title{
Greenland ice core evidence of the 79 AD Vesuvius eruption
}

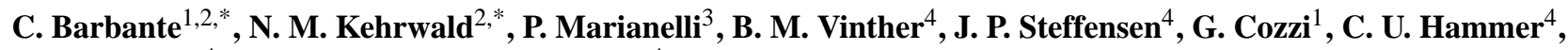 \\ H. B. Clausen ${ }^{4}$, and M.-L. Siggaard-Andersen ${ }^{4}$ \\ ${ }^{1}$ Institute for the Dynamics of the Environmental Processes, CNR, University of Venice, 30123 Venice, Italy \\ ${ }^{2}$ Department of Environmental Sciences, Informatics and Statistics, University of Venice, Ca' Foscari, 30123 Venice, Italy \\ ${ }^{3}$ Department of Earth Sciences, University of Pisa, 56126 Pisa, Italy \\ ${ }^{4}$ Niels Bohr Institute, University of Copenhagen, 2100 Copenhagen, Denmark \\ ${ }^{*}$ These authors contributed equally to this work.
}

Correspondence to: C. Barbante (barbante@unive.it)

Received: 2 October 2012 - Published in Clim. Past Discuss.: 7 November 2012

Revised: 9 April 2013 - Accepted: 7 May 2013 - Published: 13 June 2013

\begin{abstract}
Volcanic tephra are independent age horizons and can synchronize strata of various paleoclimate records including ice and sediment cores. The Holocene section of the Greenland Ice Core Project (GRIP) ice core is dated by multi-parameter annual layer counting, and contains peaks in acidity, $\mathrm{SO}_{4}{ }^{2-}$ and microparticle concentrations at a depth of 429.1 to $429.3 \mathrm{~m}$, which have not previously been definitively ascribed to a volcanic eruption. Here, we identify tephra particles and determine that volcanic shards extracted from a depth of $429.3 \mathrm{~m}$ in the GRIP ice core are likely due to the $79 \mathrm{AD}$ Vesuvius eruption. The chemical composition of the tephra particles is consistent with the K-phonolitic composition of the Vesuvius juvenile ejecta and differs from the chemical composition of other major eruptions ( $\geq$ VEI 4 ) between 50-100 AD.
\end{abstract}

\section{Introduction}

Major volcanic eruptions are phenomena which have dramatic consequences for climate and human lives. Volcanic tephra can blanket landscapes thousands of kilometers from the eruptive site (Davies et al., 2005) thereby destroying underlying vegetation and property. In many cases vast amounts of sulfuric acid $\left(\mathrm{H}_{2} \mathrm{SO}_{4}\right)$ and associated aerosols pollute the stratosphere for several years. This stratospheric veil reduces the solar radiation reaching earth's surface and causes a general cooling for months to decades (Briffa et al., 1998). The climatic impact of volcanos depends on the volume of aerosols injected into the stratosphere as well as the geo- graphic site of the eruption. Major low-latitude explosive volcanoes that inject $\mathrm{H}_{2} \mathrm{SO}_{4}$ into the stratosphere are capable of cooling the global climate for several years (Kelly et al., 1996 and references within). The most recent extreme examples of such global cooling include the eruption of Tambora, Indonesia, resulting in the "year without a summer" (Stothers, 1984; Briffa et al., 1998) or Pinatubo, Philippines, which masked global warming trends during the 1990s (Soden et al., 2002). Knowledge of past volcanic activity, especially eruptions which have sufficiently polluted the stratosphere to influence the climate over several years, is essential to interpreting past climatic trends.

Ice cores from polar ice sheets offer quantitative and welldated records of past volcanic activity reaching back several millennia (Davies et al., 2010; Lowe, 2011; Zielinski et al., 1996). The volcanic signals observed in ice cores include increased concentrations of sulfuric acid and/or sulfates. Volcanos release $\mathrm{SO}_{2}$ into the atmosphere which oxidizes in the eruption plume to form $\mathrm{H}_{2} \mathrm{SO}_{4}$ (Rampino and Self, 1982; Langway et al., 1988; Bluth et al., 1993). The conversion of $\mathrm{SO}_{2}$ into $\mathrm{H}_{2} \mathrm{SO}_{4}$ facilitates transport of volcanic emissions to the polar regions as $\mathrm{H}_{2} \mathrm{SO}_{4}$ is able to reach the stratosphere. This atmospheric height means that even $\mathrm{H}_{2} \mathrm{SO}_{4}$ that forms in low-latitude volcanic clouds can eventually reach the polar regions (Rampino and Self, 1982; Langway et al., 1988). Volcanically produced acids including $\mathrm{H}_{2} \mathrm{SO}_{4}$ are scavenged by precipitation and are deposited by snow onto the Greenland ice sheet (Clausen and Hammer, 1988; Langway et al., 1988; Clausen et al., 1997; Zielinski and Germani, 1998). During years without major eruptions the snow falling onto the ice 
sheet only contains background amounts of $\mathrm{H}_{2} \mathrm{SO}_{4}$. This alternation ultimately creates ice layers with varying acid concentrations. The volcanic $\mathrm{H}_{2} \mathrm{SO}_{4}$ preserved in ice cores can be detected as acidity peaks determined from electrical conductivity measurements (ECM) values and/or as increased concentrations in sulfate ions $\left(\mathrm{SO}_{4}{ }^{2-}\right)$ (Clausen et al., 1997; Bigler et al., 2007; Davies et al., 2010). Volcanos also eject $\mathrm{HCl}$ and $\mathrm{HF}$ into their plume which may work to enhance the ECM signals (Langway et al., 1988; Clausen et al., 1997).

The intensity of the volcanic signal recorded in polar ice cores depends to some extent on the eruption site, where neighboring volcanoes have a greater impact than lowlatitude eruptions. Greenland ice cores mainly record Northern Hemisphere volcanic activity (e.g., Clausen and Hammer, 1988; Langway et al., 1988; Clausen et al., 1997) although it has been speculated that a few Southern Hemisphere eruptions such as 186 AD Taupo, New Zealand, may have reached sufficient stratospheric heights $(55 \mathrm{~km})$ that they were deposited on the the Greenland ice sheet (Hammer, 1984; Zielinski et al., 1994). When a volcanic signal is faint in the ice core stratigraphy additional information is generally required in order to identify the eruption. Acidity peaks are not always indicative of volcanic eruptions (Davies et al., 2010) and additional information may be necessary to develop more robust conclusions to determine if an ice layer indicates a past eruption. Often only the chemical signature or presence of micrometer size tephra particles in the ice helps to "fingerprint" the acidity signal to a specific eruption site.

Volcanoes eject silicate particles with distinct chemical compositions and these airborne glass particles are deposited on ice sheets. Due to their size and insolubility in the atmosphere, these particles are often deposited as dry deposition on glacier surfaces before the other byproducts such as $\mathrm{H}_{2} \mathrm{SO}_{4}$ arrive (Hammer et al., 2003; Vinther et al., 2006; Davies et al., 2010). This difference in depositional timing sometimes leads to tephra horizons in ice cores located stratigraphically below $\mathrm{H}_{2} \mathrm{SO}_{4}$ peaks. Individual glass shards can be extracted from the ice layers and can be matched to the the chemical composition of tephra from known eruptions (Palais et al., 1990) to determine the source of the volcanic material. Developments in analyzing and geographically compiling data on tephra horizons in ice cores that are not easily seen by the naked eye have widely expanded our knowledge regarding the scope and impact of past volcanic eruptions (Davies et al., 2010 and references within). Tephra forms independent marker horizons across distances up to thousands of kilometers and allows the synchronization of ice and marine core records (Davies et al., 2005, 2010; Blockley et al., 2007).

The number of eruptive explosions with well-documented historical information are limited, and the majority of observational data on volcanic activity exists from $1500 \mathrm{AD}$ until present (e.g., Lamb, 1970). One exception is the Vesuvius eruption in $79 \mathrm{AD}$ that resulted in the destruction of Pompeii and Herculaeum (Sheridan et al., 1981). The concensus of historical data and volcanological literature suggests that the eruption occurred between 24-25 August, 79 AD (Stothers and Rampino, 1983). The Vesuvius eruption may be the oldest eruption that can be dated to an exact year (Zielinski and Germani, 1998) and is therefore an important horizon for synchronizing chronologies.

The famous observations of Pliny the Younger form the bulk of the historical record of the $79 \mathrm{AD}$ Vesuvius eruption, and the term "plinean" is applied to eruptions characterized by a basal gas thrust and an upper steady sustained convective column (Cioni et al., 2000). The deposits of the 79 AD eruption record a complex eruptive sequence, with a thick blanket of pyroclastic fall and flow products covering the volcano and a wide surrounding area. During the plinian phase a mixture of gas and tephra particles were injected into the atmosphere which returned to the surface primarily by dry deposition (Carey and Sigurdsson, 1987; Cioni et al., 1992, 2000; Sigurdsson et al., 1990). The plinian phase created two composite eruption units formed by a sequence of white and grey pumice intercalated by ash flow. Deposits are compositionally zoned from early phonolitic white pumice to late phonotephritic grey pumice. In both the white and grey pumice the main phenocrysts are sanidine and clinopyroxene (Cioni et al., 1995). However, the groundmass of the white and grey pumice varies where the white pumice is characterized by colorless glass while the grey matrix contains a greater percentage of brown glass microliths. The white pumice forms a SSE dispersal fan and deposits record a progressive increase of magma discharge rate (up to $8 \times 10^{7} \mathrm{~kg} \mathrm{~s}^{-1}$ ) resulting in the continuous rise of a convective column up to $26 \mathrm{~km}$. The grey pumice has a SE dispersal, with a slight counterclockwise rotation with respect to the white pumice axis. Following the shift in magma composition a new, rapid increase of magma discharge rate (up to $1.5 \times 10^{8} \mathrm{~kg} \mathrm{~s}^{-1}$ ) occurred with the growth of a column up to $32 \mathrm{~km}$ (Carey and Sigurdsson, 1987; Sigurdsson et al., 1990). The final phreatomagmatic phase caused pyroclastic flows and surges following the caldera collapse (Carey and Sigurdsson, 1987; Cioni et al., 1992, 2000). These high-temperature avalanches of gas and dust caused the majority of ground damage but due to their surficial nature likely did not cause any major contribution to the stratospheric tephra. The height of the convective columns reaching the stratosphere suggest that tephra and volcanic acids could reach the Greenland ice sheet surface.

The Greenland Ice Core Project (GRIP) ice core from the summit region in central Greenland $\left(72.58^{\circ} \mathrm{N}, 37.63^{\circ} \mathrm{W}\right.$, $3232 \mathrm{~m}$ a.s.1.) and the North Greenland Ice Core Project (NGRIP; $75.1^{\circ} \mathrm{N}, 42.32^{\circ} \mathrm{W}, 2917 \mathrm{~m}$ a.s.l.) ice core are multiparameter archives of climate dated for the past $60000 \mathrm{yr}$ from their stratigraphic records (Hammer et al., 1997; Svensson et al., 2008). The Greenland Ice Core Chronology 2005 (GICC05) (Rasmussen et al., 2006; Vinther et al., 2006; Andersen et al., 2006; Svensson et al., 2008) serves as a paragon for determining the chronology of other climate records, and thus it is essential to study independent markers within ice 
layers with as much precision as possible. Here, we investigate the GRIP ice core between 428 to $430 \mathrm{~m}$ depth to determine if evidence of the $79 \mathrm{AD}$ Vesuvius eruption is preserved in the ice strata.

\section{Experimental section}

\subsection{Field sampling}

The $3029 \mathrm{~m}$ GRIP ice core was drilled at the summit of the Greenland ice cap from 1989-1992. The $10 \mathrm{~cm}$ diameter core was first cut into $55 \mathrm{~cm}$ lengths and then sub-sampled with longitudinal cuts for further measurements. A continuous $\sim 2 \mathrm{~mm}$ resolution ECM acidity profile was created in situ in the GRIP sub-surface laboratories. The ECM profile reveals acid peaks ascribed to volcanic signals through the Holocene and constituted the basis for selecting ice core sequences for more detailed chemical analysis (Clausen et al., 1997). More than 100000 samples were cut in situ using a stainless steel band saw for laboratory analyses of stable oxygen isotopes $\left(\delta^{18} \mathrm{O}\right)$ (Johnsen et al., 1997). The seasonal variation of $\delta^{18} \mathrm{O}$ provided the basis of precise stratigraphic dating back to $1800 \mathrm{BC}$. Major volcanic signals were later used to tie the Holocene GRIP record to the NGRIP and DYE-3 Greenland ice core records (Johnsen et al., 1997; Vinther et al., 2006), resulting in an estimated dating accuracy of $\pm 2 \mathrm{yr}$ for the $2000 \mathrm{yr}$ old ice strata (Hammer et al., 1997).

\subsection{Sample preparation}

\subsubsection{Decontamination}

The ECM data demonstrate only one major peak (429.1 m depth) between 60 to $90 \mathrm{AD}$ (Fig. 1). We concentrated our study on the ice strata between 428.4 to $429.6 \mathrm{~m}$ depth, which correspond to an initial age range of 77 to $82 \mathrm{AD}$. We decontaminated 2 ice core sections $(3 \mathrm{~cm} \times 3 \mathrm{~cm}$ wide, $55 \mathrm{~cm}$ long $)$ under a laminar flow clean bench in a $-20^{\circ} \mathrm{C}$ cold room. We used stainless steel chisels to mechanically remove successive veneers of ice from the outer periphery of the core sections. The inner core obtained after chiseling was divided into 16 equal depth intervals.

\subsubsection{Microparticle and major ion sample preparation}

Decontaminated samples for major ions remained frozen in Coulter Accuvettes until just before analysis when they were melted under a Class 100 laminar flow bench at the University of Copenhagen (Steffensen, 1997). Dust concentrations were measured by melting a groove along a decontaminated ice core section and measuring the intensity of 90 degree scattered laser light $(633 \mathrm{~nm})$ in the melt water stream (Hammer et al., 1985). The laser light system was calibrated by measuring sequences of samples on both the laser system and Coulter counter. Major ion samples were measured using a

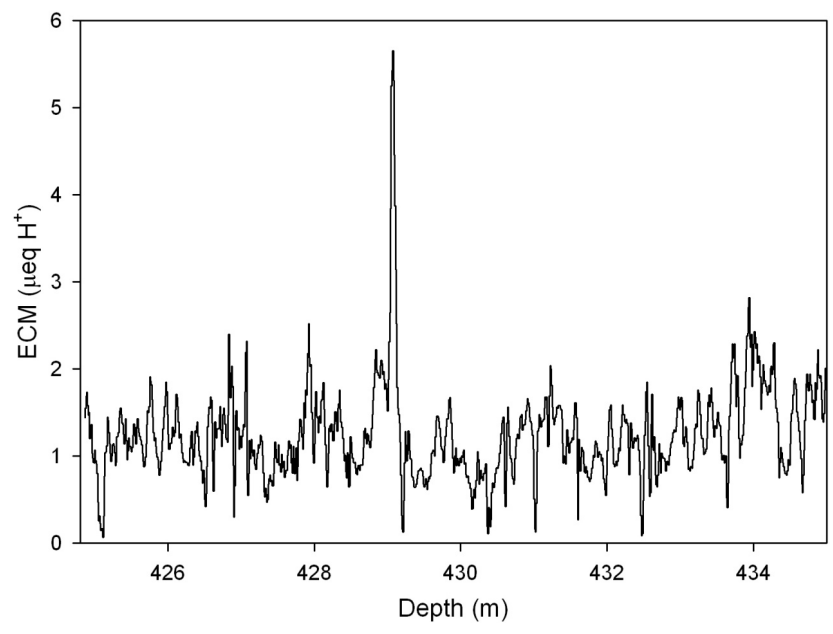

Fig. 1. Acid concentrations in the GRIP ice core determined by high-resolution electrical conductivity measurements (ECM) over $425-435 \mathrm{~m}$. The acid spike is attributed to the $79 \mathrm{AD}$ eruption in the GICC05 chronology (Vinther et al., 2006).

DX 500 ion chromatograph at the University of Copenhagen on the same ice sections as the samples used for microparticle analysis.

\subsubsection{SEM-EDS sample preparation}

The decontaminated samples were filtered using a Millipore (Bedford, MA, USA) stainless steel filtration system mounted on a high density polyethylene (HDPE) support that was cleaned in a $10 \%$ ultrapure nitric acid bath and then a Milli-Q bath for a week in a Class 100 clean room. Polycarbonate Millipore filters (porosity $0.4 \mathrm{~mm}$; diameter $13 \mathrm{~mm}$ ), previously cleaned using successive 0.1 and $0.01 \%$ ultrapure diluted nitric acid baths, were used for sample filtration. The filters containing the samples were kept frozen at $-20^{\circ} \mathrm{C}$ until the day of their analysis. Immediately preceding their analysis, individual filters were fixed with double-sided tape onto aluminum stubs and then carbon coated in order to amplify sample conductivity.

\subsection{Analytical techniques}

\subsubsection{SEM-EDS}

Individual particle analyses of the 16 samples were conducted using a Scanning Electron Microscope with an Energy Dispersive System (SEM-EDS, Philips XL30 equipped with an X-ray energy dispersive spectrometer, EDAX DX4) at the Department of Earth Sciences, University of Pisa. Instrumental conditions included $20 \mathrm{kV}$ accelerating energy and $1 \mathrm{nA}$ beam current. Before each session the quality of the analyses was checked using certified minerals and glasses as reference standards (Marianelli and Sbrana, 1998). The 25 micron micrometer sample size and unpolished specimen 
surfaces limits the accuracy of SEM-EDS analyses of tephra (Kuehn et al., 2011). The EDAX software normalizes analyses to 100 resulting in the analytical error affecting mainly the more abundant elements (i.e., $\mathrm{SiO}_{2}$ and $\mathrm{Al}_{2} \mathrm{O}_{3}$ ). Only one of the 16 filters contained tephra particles, where the filtered sample from $429.3 \mathrm{~m}$ depth contained 6 tephra particles (Table 1). The particles did not have any inclusions or secondary particles accreted on the tephra surfaces, and such a homogenous structure improves the accuracy of the SEM-EDS analyses.

The quality of analyses was determined using certified minerals and glasses as reference standards including CFA47 trachytic, ALV981R23 basaltic, and KE12 pantelleritic glasses (Table 1). Accuracy and precision of each oxide and used standard are reported in Marianelli and Sbrana (1998), although all standards were measured as polished surfaces. SEM-EDS microanalysis was carried out on individual particles using a Philips XL30 EDAX DX4. Operating conditions were $20 \mathrm{kV}$ and $\sim 0.1 \mathrm{nA}$ beam current, 2200 CPS, the X-ray take off angle was $35^{\circ}$, the working distance was $10 \mathrm{~mm}$, specimen tilt was $0^{\circ}$, the elevation angle was $35^{\circ}$, and the azimuth was $45^{\circ}$. A raster area of about $100 \mu \mathrm{m}^{2}$ was employed for glass analysis to reduce the light element loss. The analyses were normalized to $100 \mathrm{wt} \%$ using the associated EDAX. Analytical results, errors, reproducibility and detection limits using international standards for the SEM-EDS technique are reported in Marianelli and Sbrana (1998). The tephra investigated in this study are alkali-rich, which limits the number of international or certified standards with suitable compositions.

When performing EDS analyses on glasses, a raster area of $100 \mu \mathrm{m}^{2}$ is usually used to prevent the loss of sodium (Na). The size of the analyzed particles prevents the application of such a large raster area, so we applied the empirical correction method proposed by Nielsen and Sigurdsson (1981) in order to control the time-dependent loss in intensity of the $\mathrm{Na}$ line during the electron bombardment. The Na decay curve was determined on homogenous and microlith-free glasses from white pumice filtered from the ice strata assumed to be $79 \mathrm{AD}$. We collected several spectra at $10,20,30,40, \ldots 100 \mathrm{~s}$ live times in order to make a regression line and extrapolate the $\mathrm{Na}$ content at $0 \mathrm{~s}$, before any $\mathrm{Na}$ diffusion occurs (Nieslen and Sigurdsson, 1981). A least squares fit of the sodium decay curve as a function of time during electron bombardment was determined. The regression line gives initial $\mathrm{Na}$ concentration under normal operating conditions (100 s live time) and assuming that the $\mathrm{Na}$ decay begins at $t=0$. Analyses (100 s live time) were then corrected for the estimated $\mathrm{Na}$ loss (up to $25 \%$ for $79 \mathrm{AD}$ Vesuvius phonolites) and then normalized to 100 .

\subsubsection{Major ions and microparticle concentrations}

Microparticle concentrations were measured at the University of Copenhagen with a Coulter Multisizer II with a $20 \mu \mathrm{M}$ orifice (Steffensen, 1997). Here, we examine samples from 428.4 to $429.6 \mathrm{~m}$ depth to examine if a spike in the particulate concentrations ratios were present over the relevant ice core section. The major inorganic soluble components $\left(\mathrm{NO}_{3}{ }^{-}, \mathrm{SO}_{4}{ }^{2-}, \mathrm{F}^{-}, \mathrm{Cl}^{-}, \mathrm{Mg}^{2+}, \mathrm{Ca}^{2+}, \mathrm{K}^{+}, \mathrm{NH}_{4}{ }^{+}, \mathrm{Na}^{+}\right.$, $\left.\mathrm{Li}^{+}, \mathrm{MSA}\right)$ were determined at the University of Copenhagen with a Dionex 4000i ion chromatograph (Steffensen, 1997) to explore if the acid peak revealed by the in situ ECM measurements at $429.1 \mathrm{~m}$ correlated with major ions potentially caused by a volcanic eruption. Each sample was melted prior to measurement and decanted into $5 \mathrm{~mL}$ vials for automatic injection into the ion chromatograph.

\section{Results and discussion}

The GRIP ice core contains an acidity peak at $429.1 \mathrm{~m}$ as revealed by ECM data (Fig. 1). This acid peak is a common signal in Greenland ice cores including DYE-3 and NGRIP (Clausen et al., 1997; Vinther et al., 2006) and was originally dated to $80 \mathrm{AD}$ in the DYE-3 ice core based on multiparameter annual layer counting (Clausen et al., 1997). Later this date was revised to $79 \mathrm{AD}$ in the GICC05 dating effort (Vinther et al., 2006) based on the assumption that the acidity peak derived from the Vesuvian eruption. Species other than $\mathrm{H}_{2} \mathrm{SO}_{4}$ may influence the ECM and so parallel investigations of sulfate concentrations help determine if acidity peaks indicate an increase in $\mathrm{H}_{2} \mathrm{SO}_{4}$ and hence may be a marker of volcanic activity (Taylor et al., 1997). Ion chromatograph measurements clearly demonstrate that the acid peak was caused by sulfuric acid and therefore is the result of a volcanic eruption (Fig. 2).

The isotopic and major ion records (Figs. 2 and 3) demonstrates that the major deposition of sulfuric acid on the ice sheet lasted between 0.5 to $0.7 \mathrm{yr}$. The slightly elevated sulfate concentrations and acidity from 428.8 to $429.0 \mathrm{~m}$ suggest that a fraction of the volcanic acid may also have been deposited during the following year. This elevated sulfur signal for more than one season agrees with suggestions by Davies et al. (2010) that sulfuric acid may be deposited on ice sheets months after the volcanic eruption.

Elevated sulfuric acid concentrations should be doublechecked with tephra layers to provide conclusive proof of the source of past volcanic activity (Davies et al., 2010). Both differences in atmospheric transport paths and preferential gravitational settling of the tephra particles can result in their deposition on ice sheet surfaces before the stratospherically transported sulfuric acid arrives in snowfall, resulting in stratigraphic offsets between the two materials (Vinther et al., 2006; Davies et al., 2010). Microparticle concentrations (Fig. 2) peak between 429.15 and $429.25 \mathrm{~m}$, and are stratigraphically below the sulfuric acid peak at $429.1 \mathrm{~m}$. The microparticle profile in a core sequence only serves to indicate if an unusually high concentration of particles are present rather than serving as a guaranteed indicator of where to 
Table 1. Concentrations (wt \%) of major oxides and $\mathrm{Cl}$ in the six micrometer-sized volcanic glass particles and two sanidine fragments found at a depth of $429.3 \mathrm{~m}$ in the GRIP ice core. Mean and standard deviations from $10 \mathrm{~K}$-phonolitic volcanic glasses from the $79 \mathrm{AD}$ eruption (data from Balcone-Boissard et al., 2009). Totals have been normalized to $100 \%$. The standard reference materials are included, where $n$ is the number of times these reference materials were analyzed.

\begin{tabular}{|c|c|c|c|c|c|c|c|c|c|c|}
\hline \multicolumn{11}{|c|}{ Particles analyzed in this study } \\
\hline & Particle 1 & Particle 2 & Particle 3 & Particle 4 & Particle 5 & Particle 6 & Sanidine 1 & Sanidine 2 & Vesuvius & Vesuvius (SD \%) \\
\hline $\mathrm{SiO}_{2}$ & 61.36 & 60.52 & 56.42 & 57.12 & 57.30 & 57.75 & 61.30 & 63.66 & 55.55 & 0.39 \\
\hline $\mathrm{TiO}_{2}$ & 0.92 & 0.34 & 0.63 & 0.57 & 0.66 & 0.58 & & & 0.25 & 0.08 \\
\hline $\mathrm{Al}_{2} \mathrm{O}_{3}$ & 19.93 & 21.14 & 20.41 & 20.90 & 20.97 & 21.16 & 20.95 & 18.74 & 22.42 & 0.20 \\
\hline $\mathrm{FeO}$ & 0.77 & 0.30 & 4.63 & 4.79 & 3.63 & 2.48 & 4.65 & 0.27 & 2.35 & 0.22 \\
\hline $\mathrm{MgO}$ & 0.14 & 0.10 & 1.29 & 1.19 & 0.93 & 0.79 & & & 0.20 & 0.02 \\
\hline $\mathrm{CaO}$ & 2.95 & 3.71 & 3.11 & 2.99 & 3.19 & 3.03 & 0.17 & 0.00 & 2.56 & 0.09 \\
\hline $\mathrm{Na}_{2} \mathrm{O}$ & 7.54 & 9.46 & 5.64 & 5.11 & 5.63 & 6.53 & 1.22 & 1.99 & 6.66 & 0.07 \\
\hline $\mathrm{K}_{2} \mathrm{O}$ & 6.21 & 4.25 & 7.04 & 6.70 & 6.84 & 7.14 & 10.57 & 14.87 & 9.89 & 0.13 \\
\hline $\mathrm{P}_{2} \mathrm{O}_{5}$ & 0.00 & 0.16 & 0.19 & 0.00 & 0.11 & 0.10 & & & & \\
\hline $\mathrm{Cl}$ & 0.18 & 0.02 & 0.64 & 0.63 & 0.74 & 0.44 & & & 0.33 & 0.05 \\
\hline $\mathrm{BaO}$ & & & & & & & 1.13 & 0.47 & & \\
\hline \multicolumn{11}{|c|}{ Standard Reference Materials } \\
\hline & Olivine & Ortose & Diopside & Albite & Scapolite & Alvin & KE12 & CFA47 & Apatite & \\
\hline$n$ & 20 & 23 & 25 & 29 & 10 & 15 & 10 & 16 & 12 & \\
\hline $\mathrm{SiO}_{2}$ & 41.19 & 65.13 & 55.17 & 68.16 & 33.64 & 49.73 & 70.99 & 61.49 & & \\
\hline $\mathrm{SD}$ & 0.13 & 0.12 & 0.16 & 0.18 & 0.09 & 0.33 & 0.10 & 0.20 & & \\
\hline $\mathrm{SD} \%$ & 0.30 & 0.18 & 0.29 & 0.26 & 0.27 & 0.67 & 0.14 & 0.33 & & \\
\hline $\mathrm{TiO}_{2}$ & & & & & & 1.24 & 0.34 & 0.54 & & \\
\hline SD & & & & & & 0.09 & 0.06 & 0.10 & & \\
\hline $\mathrm{SD} \%$ & & & & & & 7.17 & 17.48 & 17.84 & & \\
\hline $\mathrm{Al}_{2} \mathrm{O}_{3}$ & & 16.75 & 0.66 & 20.10 & 28.93 & 16.73 & 7.78 & 18.71 & & \\
\hline SD & & 0.10 & 0.06 & 0.12 & 0.15 & 0.08 & 0.06 & 0.09 & & \\
\hline SD\% & & 0.63 & 9.10 & 0.62 & 0.53 & 0.49 & 0.75 & 0.51 & & \\
\hline $\mathrm{FeO}$ & 7.72 & 1.82 & 0.92 & & 0.15 & 8.51 & 8.42 & 2.81 & & \\
\hline SD & 0.08 & 0.07 & 0.07 & & 0.05 & 0.20 & 0.11 & 0.07 & & \\
\hline $\mathrm{SD} \%$ & 1.09 & 3.67 & 7.70 & & 33.33 & 2.38 & 1.31 & 2.49 & & \\
\hline $\mathrm{MgO}$ & 50.69 & & 17.55 & & & 8.69 & & 0.46 & & \\
\hline SD & 0.13 & & 0.10 & & & 0.14 & & 0.08 & & \\
\hline SD\% & 0.25 & & 0.57 & & & 1.57 & & 18.21 & & \\
\hline $\mathrm{CaO}$ & & & 25.30 & 0.17 & 13.68 & 11.94 & 0.34 & 1.87 & 54.93 & \\
\hline SD & & & 0.11 & 0.04 & 0.14 & 0.26 & 0.06 & 0.06 & 0.24 & \\
\hline $\mathrm{SD} \%$ & & & 0.44 & & 1.05 & 2.16 & 17.65 & 3.21 & 0.43 & \\
\hline $\mathrm{Na}_{2} \mathrm{O}$ & & 0.95 & 0.40 & 11.35 & 14.48 & 2.83 & 7.14 & 5.38 & & \\
\hline $\mathrm{SD}$ & & 0.04 & 0.07 & 0.08 & 0.07 & 0.05 & 0.08 & 0.08 & & \\
\hline SD\% & & 4.24 & 17.93 & 0.71 & 0.46 & 1.90 & 1.14 & 1.54 & & \\
\hline $\mathrm{K}_{2} \mathrm{O}$ & & 15.36 & & 0.22 & 0.58 & 0.09 & 4.34 & 7.94 & & \\
\hline $\mathrm{SD}$ & & 0.09 & & 0.05 & 0.03 & 0.03 & 0.03 & 0.10 & & \\
\hline $\mathrm{SD} \%$ & & 0.58 & & & 5.03 & 33.07 & 0.69 & 1.26 & & \\
\hline $\mathrm{P}_{2} \mathrm{O}_{5}$ & & & & & & & & & 41.41 & \\
\hline SD & & & & & & & & & 0.20 & \\
\hline SD\% & & & & & & & & & 0.49 & \\
\hline $\mathrm{Cl}$ & & & & & 5.18 & & 0.32 & 0.55 & & \\
\hline SD & & & & & 0.09 & & 0.03 & 0.05 & & \\
\hline SD\% & & & & & 1.73 & & 10.30 & 8.94 & & \\
\hline S & & & & & 3.38 & 0.09 & & & & \\
\hline SD & & & & & 0.03 & 0.02 & & & & \\
\hline $\mathrm{SD} \%$ & & & & & 0.80 & 22.22 & & & & \\
\hline $\mathrm{MnO}$ & & & & & & 0.15 & 0.34 & 0.25 & & \\
\hline SD & & & & & & 0.05 & 0.03 & 0.05 & & \\
\hline SD\% & & & & & & 31.06 & 8.44 & 21.27 & & \\
\hline $\mathrm{NiO}$ & 0.40 & & & & & & & & & \\
\hline SD & 0.11 & & & & & & & & & \\
\hline SD\% & 26.30 & & & & & & & & & \\
\hline F & & & & & & & & & 3.66 & \\
\hline SD & & & & & & & & & 0.27 & \\
\hline SD\% & & & & & & & & & 7.29 & \\
\hline
\end{tabular}




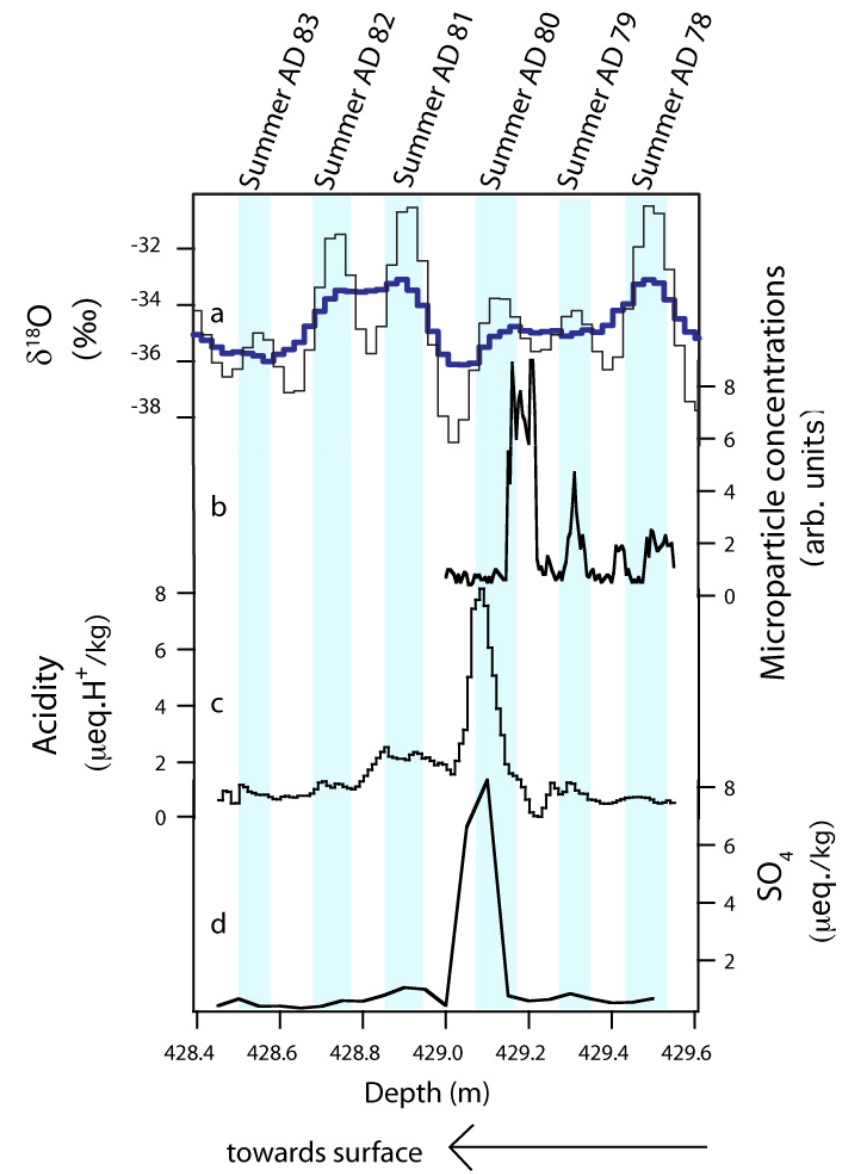

Fig. 2. High resolution $\delta^{18} \mathrm{O}$, microparticle, acidity, and sulfate concentrations from $428-430 \mathrm{~m}$ in the GRIP ice core. The blue bars highlight $\delta^{18} \mathrm{O}$ peaks ascribed to summer accumulation. The ages are from the GICC05 annual layer counting, but offset by one year to conform with the Vesuvian (August 79AD) tephra layer detected at $429.3 \mathrm{~m}$. The "arbitrary units" for the dust concentrations were determined by calibrating the signal from the laser device to Coulter counter results to obtain an arbitrary scale where $1.0 \mathrm{mV}=50 \pm 15$ micrograms kg ${ }^{-1}$ dust and $8 \mathrm{mV}=400 \pm 130$ micrograms kg $^{-1}$ dust (ash). The error associated with the dust curve is $\pm 30 \%$.

search for volcanic ash particles in a core sequence, as the majority of microparticles in Greenland ice cores originate from continental dust (Steffensen, 1997). No volcanic glass particles were found in the $429.15-429.25 \mathrm{~m}$ microparticle peak, and all microparticles had elemental chemical composition typical of continental crust. This large microparticle peak does not influence any conclusions regarding volcanic activity. However, the microparticle concentration peak at $429.3 \mathrm{~m}$ contained six tephra particles with a K-phonolitic composition (Table 1; Fig. 4). These six tephra particles extracted from the GRIP ice core comprise a limited data set, but are consistent with numbers of volcanic tephra found in Greenland ice cores (Narcisi et al., 2010 and references within). Previous analyses of volcanic glasses in Greenland

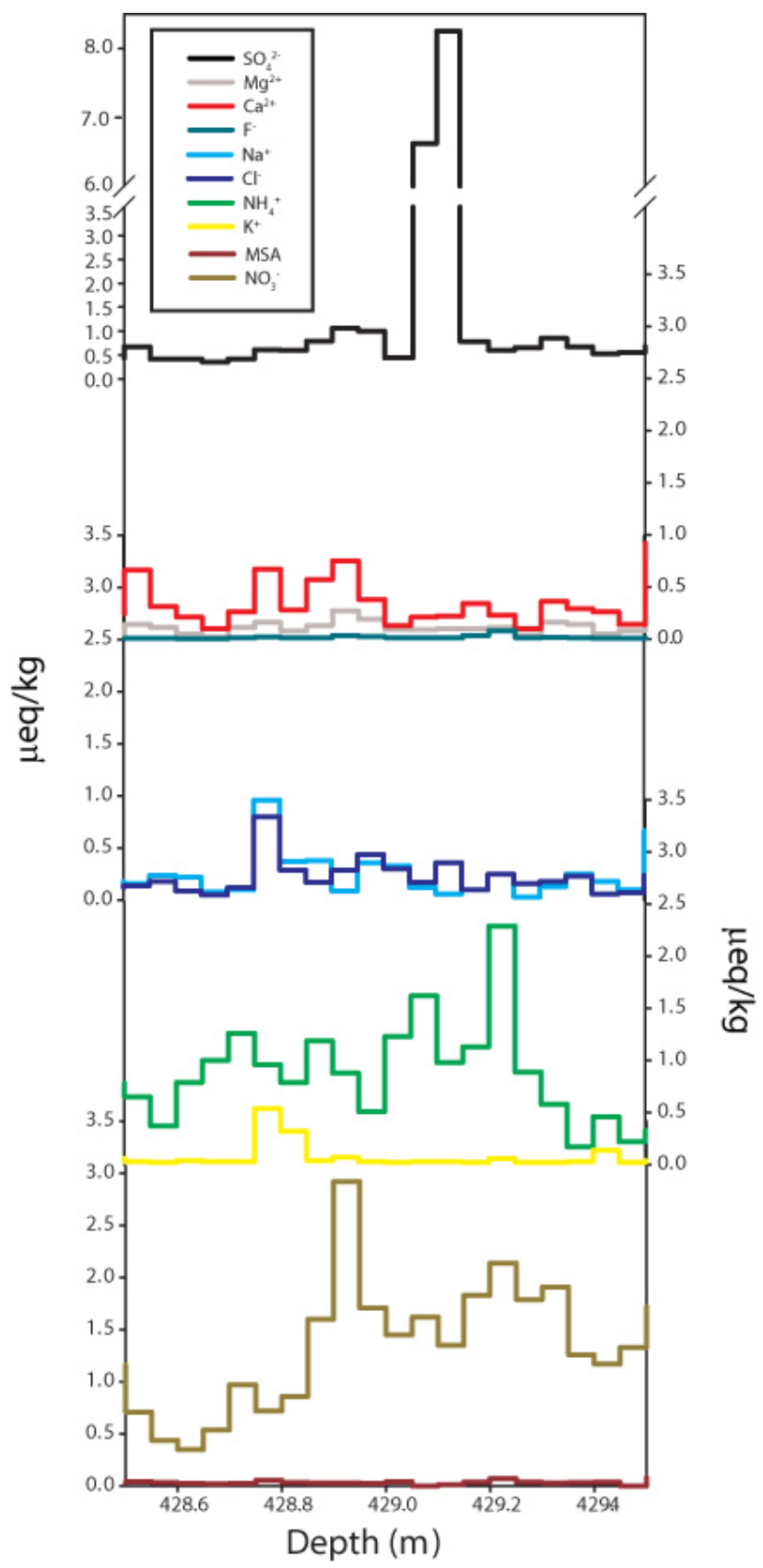

Fig. 3. Major ion concentrations in the GRIP ice core between 428.4 and $429.6 \mathrm{~m}$ depth. The $\mathrm{SO}_{4}{ }^{2-}$ peak is attributed to volcanic activity. The major ions are grouped by the information that they represent where $\mathrm{NO}_{3}{ }^{-}$and MSA are indicative of biological activity, $\mathrm{NH}_{4}{ }^{+}$and $\mathrm{K}^{+}$can be used as biomass burning markers, $\mathrm{Na}^{+}$and $\mathrm{Cl}^{-}$often represent the contribution of sea salts, and $\mathrm{Mg}_{2}{ }^{+}, \mathrm{Ca}_{2}{ }^{+}$, and $\mathrm{F}^{-}$are crustal markers.

ice cores indicate that the concentration of volcanic shards in ice may vary by orders of magnitude and can range from visible ash layers to as few as $<10$ particles per $\mathrm{kg}$ of ice (Davies et al., 2010 and references within). The presence of 


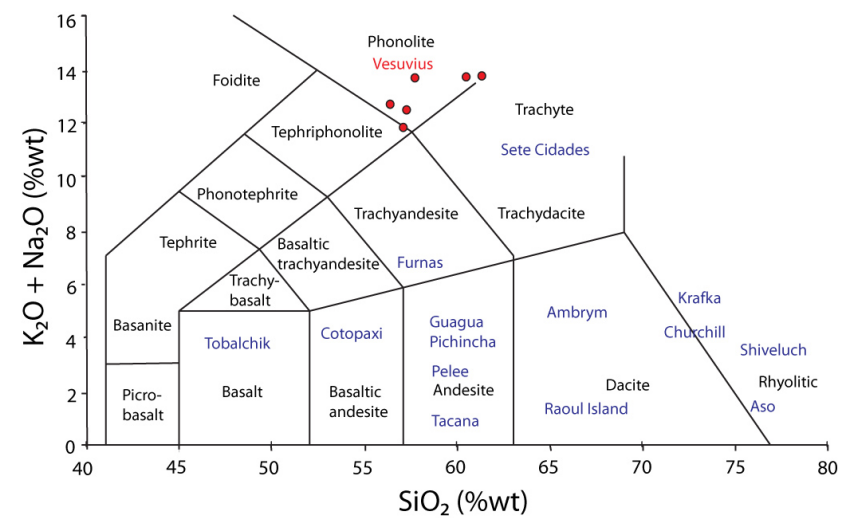

Fig. 4. Geochemical classification of major explosive volcanoes between 50 to $100 \mathrm{AD}$ (see Table 2). The volcanoes are characterized by their total alkali versus silica oxide concentrations (Le Maitre et al., 1989; Abbott and Davies, 2012). The red points are the individual tephra shards identified in the GRIP ice core at $429.2 \mathrm{~m}$ depth. The GRIP tephra are classified as phonolitic, while the other explosions (names in blue) encompass diverse geochemical classifications.

tephra in ice core records has only one possible source, and is a clear indication of past volcanic activity.

All extracted tephra are characterized as having a phonolitic composition where this composition is indicative of Vesuvius $79 \mathrm{AD}$ volcanic products (Table 1; Fig. 4; BalconeBoissard et al., 2009). For many Vesuvius eruptions, groundmass glasses generally exhibit a larger scatter than bulk rock analyses (Figs. 5 and 6). This microscale compositional heterogeneity is particularly accentuated by the large microlith content of many of the Vesuvius volcanic products (Santacroce et al., 2008). The analyzed shards in this paper do not contain microliths, as determined by visually inspecting each tephra particle with the SEM before beginning EDS analysis. In addition, the absence of characteristic spectra (ie $\mathrm{Ba}$ ) in each tephra particle further suggests the lack of microliths. Microparticles extracted from the filtered samples contained sanidine fragments (Table 1), a mineral phase very common in products of K-phonolitic eruptions. These fragments add further support for the hypothesis of Vesuvius as a source of this microparticle layer.

When compared against the total range of possible geochemical classifications, the six GRIP tephra fragments all fall within the phonolitic classification (Fig. 4). However, when comparing the tephra fragments with whole-rock and individual pumice samples from the Pompeii $70 \mathrm{AD}$ Vesuvius eruption, the GRIP particles appear relatively heterogenous (Fig. 5; Santacroce et al., 2008; Balcone-Boissard et al., 2009). The GRIP tephra all contain high alkali $\left(\mathrm{K}_{2} \mathrm{O}\right.$ and $\mathrm{Na}_{2} \mathrm{O}$ ) concentrations and biplots demonstrate that for these elements all GRIP particles are consistent with previously determined Vesuvius chemistry (Fig. 5). This high alkali concentration is important as, when comparing the Vesu-

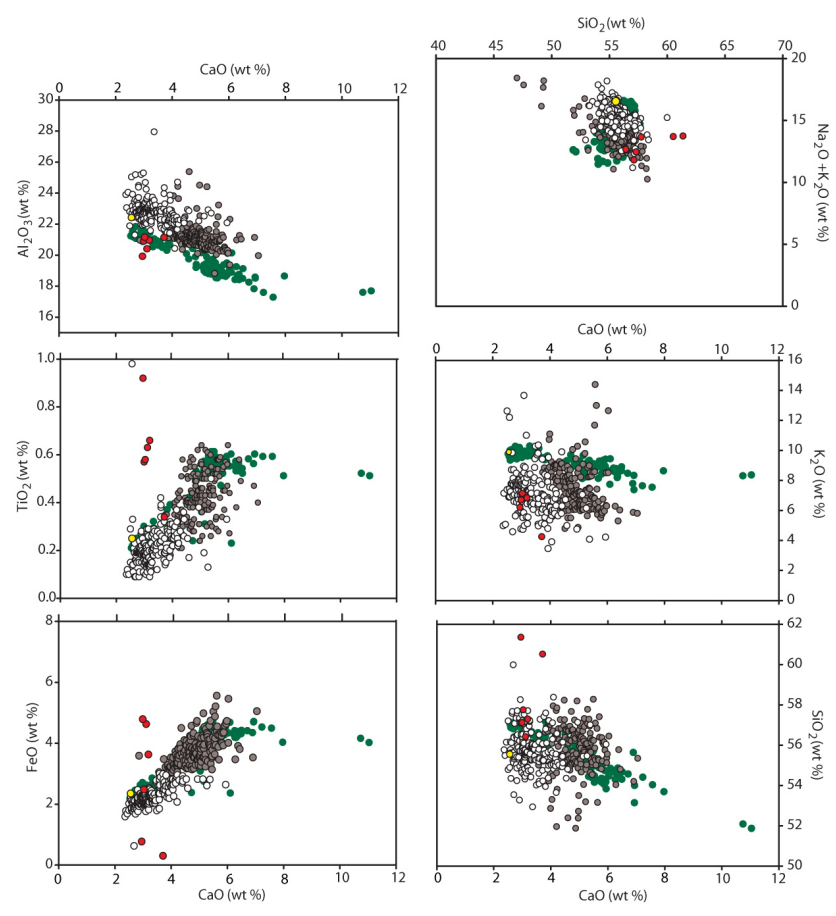

Fig. 5. Biplots comparing the chemical composition of the tephra shards extracted from $429.2 \mathrm{~m}$ depth in the GRIP ice core (red, this study) with whole rock (green), grey pumice (grey) and white pumice (white) Vesuvius 79 AD proximal deposits (Supplement in Santacroce et al., 2008). The yellow dots provide mean values for Vesuvius white pumice deposits (Balcone-Boissard et al., 2009).

vius eruption to coeval (50-100 AD) eruptions, only Vesuvius and eruptions from the Azores have high alkali concentrations (Fig. 4; Table 2). The GRIP tephra differ from the Vesuvius values in $\mathrm{FeO}$ and $\mathrm{TiO}_{2}$ versus $\mathrm{CaO}$ biplots (Fig. 5), yet the range of $\mathrm{Fe}$ and $\mathrm{Ti}$ weight percentages remain within or close to those of Vesuvius (Figs. 5 and 6). It is difficult to compare the GRIP $\mathrm{FeO}$ and $\mathrm{TiO}_{2}$ values to other sources as using SEM-EDS to determine these oxides results in a high percentage of standard deviation even when analyzing standard reference materials (Table 1). Particles 1 and 2 contain higher $\mathrm{SiO}_{2}$ values than the other tephra and plot near the phonolite-trachyte boundary (Table 1; Fig. 4), suggesting that the Sete Cidades $(90 \pm 100 \mathrm{AD})$ eruption could be a source of these two particles. Comparing the geochemical composition of particles 1 and 2 to ejecta from the Sete Cidades eruption could illuminate if these particles are from the Azores, but to the best of our knowledge, no detailed geochemical analysis of the 90 AD Sete Cidades tephra exists. As particles 1 and 2 remain within the phonolitic chemical characterization (Fig. 4) and as they are similar to other GRIP and Vesuvius products (Fig. 5), we assume that they are from the same source as the other GRIP tephra.

Between 50 to $100 \mathrm{AD}$ eruptive products from relatively coeval volcanoes with a similar eruptive strengths could have potentially reached the Greenland ice sheet (Table 2). The 
Table 2. Known major volcanic eruptions between 50-100 AD. The Krafla, Iceland, eruption is included due to its proximity to the GRIP ice core site. Other than the Krafla and Asos eruptions, the volcanic explosivity index (VEI) data are compiled in the Smithsonian Global Volcanism Program (http://www.volcano.si.edu/world/largeeruptions.cfm).

\begin{tabular}{|c|c|c|c|c|c|c|c|}
\hline Eruption & Location & Year & VEI & Tephra volume & Eruptive characteristics: & $\begin{array}{l}\text { Magma and/or tephra } \\
\text { composition }\end{array}$ & References \\
\hline Tolbachik & Kamchatka & $50 \mathrm{AD}(?)$ & $4+$ & $9.0 \times 10^{8} \mathrm{~m}^{3}$ & $\begin{array}{l}\text { Flank (excentric) vent } \\
\text { Radial fissure eruption } \\
\text { Explosive eruption } \\
\text { Lava flow(s) }\end{array}$ & $\begin{array}{l}\text { High-MgO and } \\
\text { high-Al,O, basalts. }\end{array}$ & $\begin{array}{l}\text { Doubik and Hill (1999); } \\
\text { Kersting and Arculus (1995) }\end{array}$ \\
\hline Ambrym & Vanuatu & $50 \mathrm{AD} \pm 100 \mathrm{yr}$ & $6+$ & $>7.0 \times 1.0 \times 10^{10} \mathrm{~m}^{3}$ & $\begin{array}{l}\text { Central vent eruption } \\
\text { Explosive eruption } \\
\text { Pyroclastic flow(s) } \\
\text { Lava flow(s) } \\
\text { Caldera collapse }\end{array}$ & Dacite & $\begin{array}{l}\text { Baker and Condliffe (1996); } \\
\text { Robin et al. (1993) }\end{array}$ \\
\hline Krafla & Iceland & $50 \mathrm{AD}$ & 2 & & & $\begin{array}{l}\text { Tholeiitic rhyolite, } \\
\text { Icelandite, Dacite }\end{array}$ & $\begin{array}{l}\text { Lacasse and } \\
\text { Garbe-Schonberg (2001); Jonas- } \\
\text { son (1994) }\end{array}$ \\
\hline Pelee & West Indies & $50 \mathrm{AD}(?)$ & $3-6 ?$ & & $\begin{array}{l}\text { Central vent eruption } \\
\text { Explosive eruption } \\
\text { Pyroclastic flow(s) }\end{array}$ & $\begin{array}{l}\text { Course-grained andesitic } \\
\text { pumice }\end{array}$ & Westercamp and Traineau (1983) \\
\hline Churchill & Alaska & $60 \mathrm{AD} \pm 200 \mathrm{yr}$ & 6 & $>2.5 \times 10^{10} \mathrm{~m}^{3}$ & $\begin{array}{l}\text { Central vent eruption } \\
\text { Explosive eruption }\end{array}$ & Rhyodacite & Lerbekmo and Campbell (1969) \\
\hline Guagua Pichincha & Ecuador & $70 \mathrm{AD} \pm 75 \mathrm{yr}$ & 4 & $5 \times 10^{8} \mathrm{~m}^{3}$ & $\begin{array}{l}\text { Central vent eruption } \\
\text { Explosive eruption } \\
\text { Pyroclastic flow(s) }\end{array}$ & $\begin{array}{l}\text { Dacitic composition } \\
\left(61.5-65.7 \text { wt.\% } \mathrm{SiO}_{2}\right)\end{array}$ & Robin et al. (2008) \\
\hline Cotopaxi & Ecuador & $70 \mathrm{AD} \pm 150 \mathrm{yr}$ & 4 & $5.6 \times 10^{8} \mathrm{~m}^{3}$ & $\begin{array}{l}\text { Central vent eruption } \\
\text { Explosive eruption } \\
\text { Pyroclastic flow(s) }\end{array}$ & $\begin{array}{l}\text { Basaltic-andesites, } \\
\text { andesites, rhyolites }\end{array}$ & $\begin{array}{l}\text { Biass and Bonadonna (2011); } \\
\text { Garrison et al. (2011) }\end{array}$ \\
\hline Tacana & Mexico & $70 \mathrm{AD} \pm 100 \mathrm{yr}$ & $4 ?$ & $>1.2 \times 10^{8} \mathrm{~m}^{3}$ & $\begin{array}{l}\text { Flank (excentric) vent } \\
\text { Explosive eruption } \\
\text { Pyroclastic flow(s) } \\
\text { Lava flow(s) } \\
\text { Lava dome extrusion } \\
\text { Damage (land, property, etc.) } \\
\text { Mudflow(s) (lahars) } \\
\text { Evacuation }\end{array}$ & $\begin{array}{l}\text { Andesite with basilitic- } \\
\text { andesite inclusions } \\
\left(54 \% \mathrm{SiO}_{2}\right) \text { capped } \\
\text { with andecitic to dacitic } \\
\left(62-64 \% \mathrm{SiO}_{2}\right) \text { lava } \\
\text { flows }\end{array}$ & Macias et al. (2000) \\
\hline Vesuvius & Italy & $79 \mathrm{AD}$ & $5 ?$ & $3.3 \times 0.5 \times 10^{9} \mathrm{~m}^{3}$ & $\begin{array}{l}\text { Central vent eruption } \\
\text { Explosive eruption } \\
\text { Pyroclastic flow(s) } \\
\text { Fatalities } \\
\text { Damage (land, property, etc.) } \\
\text { Mudflow(s) (lahars) } \\
\text { Tsunami } \\
\text { Caldera collapse } \\
\text { Evacuation }\end{array}$ & K-phonolite & $\begin{array}{l}\text { Siggurdson et al. (1990); } \\
\text { Blacone-Boissard et al. (2009) }\end{array}$ \\
\hline Furnas & Azores & $80 \mathrm{AD} \pm 100 \mathrm{yr}$ & 5 & $1.5 \times 10^{9} \mathrm{~m}^{3}$ & $\begin{array}{l}\text { Central vent eruption } \\
\text { Explosive eruption } \\
\text { Pyroclastic flow(s) } \\
\text { Mudflow(s) (lahars) } \\
\text { resulting from magmatic and } \\
\text { hydromagmatic eruptions }\end{array}$ & $\begin{array}{l}\text { basanite and alkali } \\
\text { olivine basalt, potassic } \\
\text { trachybasalt, basaltic } \\
\text { trachyandesite (shoshon- } \\
\text { ite) trachandesite (latite) } \\
\text { to trachyte }\end{array}$ & Guest et al. (1999) \\
\hline Sete Cidades & Azores & $90 \mathrm{AD} \pm 100 \mathrm{yr}$ & 4 & $3.9 \times 10^{8} \mathrm{~m}^{3}$ & $\begin{array}{l}\text { Central vent eruption } \\
\text { Explosive eruption } \\
\text { Pyroclastic flow(s) }\end{array}$ & Trachite, & Wolff and Storey (1983) \\
\hline Aso & Japan & $100 \mathrm{AD}$ & - & & & Rhyodacite & Machida and Arai (1983) \\
\hline Raoul Island & Kermadec Islands & $100 \mathrm{AD}(?)$ & 4 & $>1 \times 10^{8} \mathrm{~m}^{3}$ & $\begin{array}{l}\text { Flank (excentric) vent } \\
\text { Explosive eruption } \\
\text { Pyroclastic flow(s) }\end{array}$ & $\begin{array}{l}\text { Pumiceous dacide } \\
\text { low } \mathrm{K} 2 \mathrm{O} \text { content } \\
\left(\_0.8 \mathrm{wt} \%\right)\end{array}$ & $\begin{array}{l}\text { Shane and Wright (2011) } \\
\text { and references within }\end{array}$ \\
\hline Shiveluch & Kamchatka & $100 \mathrm{AD}(?)$ & 4 & $5 \times 10^{8} \mathrm{~m}^{3}$ & $\begin{array}{l}\text { Central vent eruption } \\
\text { Explosive eruption }\end{array}$ & Rhyolitic & Kyle et al. (2011) \\
\hline
\end{tabular}

volcanic explosivity index (VEI) measures the magnitude and associated tephra volumes of eruptions (Newhall and Self, 1982). A VEI of 4 or greater suggests that the volcano was sufficiently explosive to have injected material into the stratosphere (Newhall and Self, 1982), and so Southern Hemisphere volcanoes with a VEI of $\geq 4$ are included in Table 2. Although stratospheric particles originiating in the
Southern Hemisphere can reach Greenland (Zielinski et al., 1994), tephra from neighboring or Northern Hemisphere volcanoes are more likely to be deposited on the ice sheet (Langway Jr. et al., 1988; Clausen and Hammer, 1988; Clausen et al., 1997). Many of the coeval eruptions, such as Ambrym, Vauatu or Raoul Island in the Kermadic Island chain, are located in areas where it is difficult for the volcanic aerosols to 

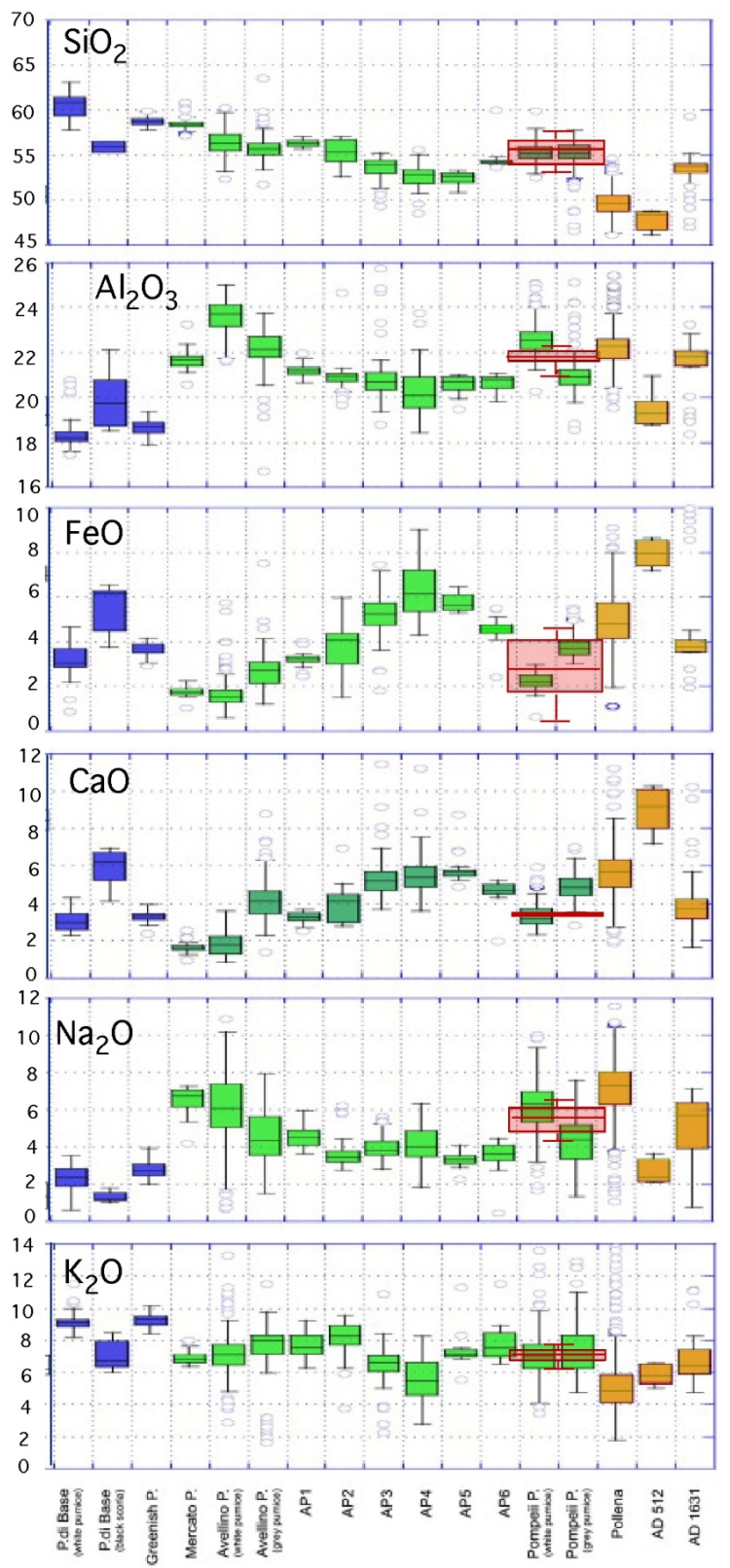

Fig. 6. Box and whiskers plots representing analyses of this work (red) compared with the range of EDS glass analyses of Vesuvius tephra (Santacroce et al., 2008). AP1 to AP6 signify explosive activity occurring between the larger Avellino and Pompeii eruptions (Santacroce et al., 2008 and references within). The box and whiskers diagrams outline the median values (middle line), the middle two quartiles (shaded boxes), outer quartiles (whiskers), and outlying values (circles). The orange boxes demonstrate the strongly $\mathrm{SiO}_{2}$-undersaturated glasses younger than $79 \mathrm{AD}$, the green boxes represent the mildy $\mathrm{SiO}_{2}$-undersaturated glasses from 8900 B.P. to $79 \mathrm{AD}$, while the blue boxes mark the composition of the slightly $\mathrm{SiO}_{2}$-undersaturated glasses older than $8900 \mathrm{BP}$ as defined by Santacroce et al. (2008). have reached the Greenland ice sheet. The K-phonolitic characteristics of the Vesuvius products differ from the composition of the tephra from known explosive eruptions between 50-100 AD (Table 2; Fig. 4). Of the coeval eruptions, only Sete Cidades and Furnas also have high alkali contents, although their geochemical classification (resulting either from higher $\mathrm{SiO}_{2}$ contents and/or lower $\mathrm{K}_{2} \mathrm{O}+\mathrm{Na}_{2} \mathrm{O}$ contents) differs from that of Vesuvius (Table 2; Fig. 4). The consistently high $\mathrm{K}_{2} \mathrm{O}$ and $\mathrm{Na}_{2} \mathrm{O}$ weight percentages of all analyzed GRIP tephra makes it unlikely that the GRIP tephra are from any known coeval volcano other than Vesuvius, Sete Cidades or Furnas (Figs. 4 and 5). The high GRIP $\mathrm{K}_{2} \mathrm{O}$ and $\mathrm{Na}_{2} \mathrm{O}$ values and their correspondence with multiple measurements of Vesuvius pumice, strongly suggest that Vesuvius is the source of these tephra.

Even if we conclude that the GRIP tephra are from Vesuvius, the fact that the Vesuvius tephra exist within the $\delta^{18} \mathrm{O}$ (warm season) peak as well as the $20 \mathrm{~cm}$ offset between the acidity peak and tephra fragments remains (Fig. 2). Historical data and volcanological literature supply ample evidence that the Vesuvius eruption occurred in August 79 AD (e.g., Lanphere et al., 2007 and references within). If the eruption occurred during September or October $79 \mathrm{AD}$, the settling of tephra into the fresh snow after the eruption and the compaction of this snow during the subsequent $\sim 2000 \mathrm{yr}$ of accumulation $(429 \mathrm{~m})$ suggests that the location of the tephra particles within the $\delta^{18} \mathrm{O}$ (warm season) peak is physically possible (Fig. 2). The stratigraphic difference between the $\delta^{18} \mathrm{O}$ peak (warm season) and the $\delta^{18} \mathrm{O}$ valley (cold season) is only $5 \mathrm{~cm}$.

An alternate explanation for the offset between the acidity and microparticle peaks is that the two peaks were caused by two separate high-VEI volcanic eruptions within a matter of months (Table 2). This argument requires that one volcano only deposited acidic volcanic aerosols, while the other volcano deposited only a few tephra particles. This is a more complex solution than explaining the difference in peak depth due to differential deposition pathways between tephra particles and volcanic gases.

In the neighboring Greenland ice sheet Project 2 (GISP2) ice core, only one $\mathrm{SO}_{4}{ }^{2-}$ peak between $0-150 \mathrm{AD}$ is attributed to a volcanic eruption (Zielinski, 1995). The cumulative dating error of the most recent $2100 \mathrm{yr}$ of the GISP2 core is $0.5 \%$, suggesting that even though $\mathrm{a} \mathrm{SO}_{4}{ }^{2-}$ peak occurs at $78 \mathrm{AD}$ on the GISP2 age scale, the $79 \mathrm{AD}$ Vesuvius eruption is a likely source (Zielinski, 1995). Our identification of tephra deposited one year before the main acidity peak in the GRIP ice core indicates that the acidity peak observed in Greenland should be assigned to the year 80 AD supporting the original DYE-3 interpretation, whereas the GICC05 timescale (shown in Fig. 2) is offset by one year. 


\section{Conclusions}

Tephra are tangible proof of volcanic activity. Our aim in this paper is to determine if tephra extracted from ice cores can identify important stratigraphic age horizons, but we do not attempt to directly change time scale development. We identified six volcanic glass fragments at $429.3 \mathrm{~m}$ depth in the GRIP ice core where the elemental compositional analysis strongly suggests that they originated from the $79 \mathrm{AD}$ Vesuvius eruption. The tephra are located $20 \mathrm{~cm}$ deeper than an acidity and $\mathrm{SO}_{4}{ }^{2-}$ peak. This offset between the location of increased acidity and $\mathrm{SO}_{4}{ }^{2-}$ is consistent with the literature as tephra can be deposited on surfaces before the stratospherically transported $\mathrm{SO}_{4}{ }^{2-}$ (Vinther et al., 2006). This low number of volcanic tephra is consistent with quantities of volcanic ejecta in polar ice cores (Narcisi et al., 2010 and references within). The $79 \mathrm{AD}$ Vesuvius eruption may be the oldest volcanic eruption with detailed historic records that can be dated to an exact year (Zielinski and Germani, 1998), and this independent tephra horizon helps extend the match between the historic and paleo records. Future work in determining the geochemical composition of tephra from highVEI eruptions and applying this characterization to tephra extracted from ice cores can help refine knowledge regarding the extent and impact of major eruptions as well as help synchronize ice core and sediment records.

Acknowledgements. This work was supported in Italy by the "Agenzia nazionale per le nuove tecnologie, l'energia e lo sviluppo economico sostenibile" (ENEA) as part of the Antarctic National Research Program (Environmental Contamination and Glaciology) and in Denmark by "Statens Naturvidenskablig Forskningsråd" (SNF) as well as the XII Directorate of CEC, the Carlsberg Foundation and the Commission for Scientific Research in Greenland. We thank L. Pozzato for laboratory assistance and A. Sbrana for the useful discussions.

Edited by: M. Albert

\section{References}

Abbott, P. M. and Davies, S. M.: Volcanism and the Greenland icecores: the tephra record, Earth-Sci. Rev., 115, 173-191, 2012.

Andersen, K. K., Svensson, A., Johnsen, S. J., Rasmussen, S. O., Bigler, M., Rothlisberger, T., Ruth, U., Siggard-Andersen, M.L., Peder Steffensen, J., Dahl-Jensen, D., Vinther, B. M., and Clausen, H. M.: The Greenland Ice Core Chronology, 15-42 ka, Part 1: constructing the time scale, Quaternary Sci. Rev., 25, 3246-3257, 2006.

Baker, P. E. and Condliffe, E.: Compositional variation in submarine volcanic ashes from the vicinity of the Vanuatu Island Arc: a reponse to ridge-arc collision?, J. Volc. Geoth. Res., 72, 225238, 1996.

Balcone-Boissard, H., Baker, D. R., Villemant, B., and Boudon, G.: $\mathrm{F}$ and $\mathrm{Cl}$ diffusion in phonolotic melts: Influence of the $\mathrm{Na} / \mathrm{K}$ ratio, Chem. Geol., 263, 89-98, 2009.
Biass, S. and Bonadonna, C.: A quantitative uncertainty assessment of eruptive parameters derived from tephra deposits: the example of two large eruptions of Cotopaxi volcano, Ecuador, Bull. Volcanol., 73, 73-90, 2011.

Bigler, M., Svensson, A., Steffensen, J. P., and Kaufmann, P.: A new continuous high-resolution detection system for sulphate in ice cores, Ann. Glaciol., 45, 178-182, doi:10.3189/172756407782282471, 2007.

Blockley, S. P. E., Lana, C. S., Lotter, A. F., and Pollard, A. M.: Evidence for the presence of the Vedde Ash in Central Europe, Quaternary Sci. Rev., 26, 3030-3036, 2007.

Bluth, G. J. S., Schnetzler, C. C., Kruger, A. J., and Walter, L. S.: The contribution of explosive volcanism to global atmospheric sulpher dioxide concentrations, Nature, 366, 327-329, 1993.

Briffa, K. R., Jones, P. D., Schweingruber, F. H., and Osborn, T. J.: Influence of volcanic eruptions on Northern Humisphere summer temperature over the past 600 years, Nature, 393, 450-454, 1998.

Carey, S. and Sigurdsson, H.: Temporal variations in column height and magma discharege rate during the $79 \mathrm{AD}$ eruption of Vesuvius, Geolog. Soc. Am. B., 99, 303-314, 1987.

Cioni, R.: Volatile content and degassing processes in the AD 79 magma chamber at Vesuvius (Italy), Contrib. Mineral. Petrol., 140, 40-54, 2000.

Cioni, R., Marianelli, P., and Sbrana, A.: Dynamics of the AD 79 eruption: stratigraphic, sedimentological and geochemical data on the successions from the Somma-Vesuvius southern and eastern sectors, Acta Vulcanol., 2, 109-123, 1992.

Cioni, R., Civetta, L., Marianelli, P., Metrich, N., Santacroce, R., and Sbrana, A.: Compositional layering and syn-eruptive mixing of a periodically refilled shallow magma chamber: The AD 79 Plinian eruption of Vesuvius, J. Petrol., 36, 739-776, 1995.

Cioni, R., Marianelli, P., Santacroce, R., and Sbrana, A.: Plinian and subplinian eruptions, in: Encyclopedia of Volcanoes, edited by: Sigurdsson, H., Academic Press, San Diego, 477-494, 2000.

Clausen, H. B. and Hammer, C. U.: The Laki and Tambora eruptions as revealed in Greenland ice cores from 11 locations, Ann. Glaciol., 10, 16-22, 1988.

Clausen, H. B., Hammer, C. U., Hvidberg, C. S., Dahl-Jensen, D., and Steffensen, J. P.: A comparison of the volcanic recors over the past 4000 years from the Greenland Ice Core Project and Dye 3 Greenland ice cores, J. Geophys. Res. 102, 27707-26723, 1997.

Davies, S. M., Hoeck, W. Z., Bohncke, S. J. P., Lowe, J. J., O'Donnell, S. P., and Turney, C. S. M.: Detection of Lateglacial distal tephra layers in the Netherlands, Boreas, 34, 123-135, 2005.

Davies, S. M., Wastegård, Abbott, P. M., Barbante, C., Bigler, M., Johnsen, S. J., Rasmusses, T. L., Steffensen, J. P., and Svensson, A.: Tracing volcanic events in the NGRIP ice-core and synchronising North Atlantic marine records during the last glacial period, Earth Planet. Sci. Lett., 294, 69-79, 2010.

Doubik, P. and Hill, B. E.: Magmatic and hydrothermal conduit development during the 1975 Tolbachik eruption, Kamchatka, with implications for hazards assessmnet at Yucca Mountain, NV, J. Volc. Geoth. Res., 91, 43-64, 1999.

Garrison, J. M., Davidson, J. P., Hall, M., and Mothes, P.: Geochemistry and petrology of the most recent deposits from Cotopaxi Volcano, northern volcanic zone, Equador, J. Petrology, 52, 1641-1678, 2011. 
Guest, J. E., Gaspar, J. L., Cole, P. D., Queiroz, G., Duncan, A. M., Wallenstein, N., Ferreira, T., and Pacheco, J.-M.,: Volcanic geology of Furnas volcano, Sao Miguel, Azores, J. Volc. Geotherm. Res., 92, 1-29, 1999.

Hammer, C. U.: Traces of Icelandic eruptions in the Greenland ice sheet, Jökull, 34, 51-65, 1984.

Hammer, C. U., Clausen, H. B., Dansgaard, W., Neftel, A., Kristinsdottir, P., and Johnson, E.: Continuous impurity analysis along the Dye-3 deep core, Greenland Ice Cores: Geophysics, Geochemistry and Environment, edited by: Langway Jr., C. C., Oeshger, H. and Dansgaard, W., American Geophysical Union (AGU), Monograph, 33, 90-94, 1985.

Hammer, C. U., Andersen, K. K., Clausen, H. B., Dahl-Jensen, D., Hvidberg, C. V., and Iversen, P.: The stratigraphic dating of the GRIP ice core, Special Report of the Geophysical Department, Niels Bohr Institute for Astronomy, Physics and Geophysics, University of Copenhagen, 1997.

Hammer, C. U., Kurat, G., Hoppe, P., Grum, W., and Clausen, H. B.: Thera eruption date $1645 \mathrm{BC}$ confirmed by new ice core data?, Proc. Of SCIEM 2000, edited by: Bietak, M., 87-94, 2003.

Johnsen, S. J., Clausen, H. B., Dansgaard, W., Gundestrup, N. S., Hammer, C. U., Andersen, U., Andersen, K. K., Hvidberg, C. S., Dahl-Jensen, D., Steffensen, J. P., Shoji, H., Sveinbjörnsdóttir, A. E., White, J., Jouzel, J., and Fischer, D.: The $\delta^{18} \mathrm{O}$ record along the Greenland Ice Core Project deep ice core and the problem of possible Eemian climatic instability, J. Geophys. Res., 102, 26397-26410, doi:10.1029/97JC00167, 1997.

Jonasson. K.: Rhyolite volcanism in the Krafka central volcano, north-east Iceland, Bull. Volcanol., 56, 516-528, 1994.

Kelly, P. M., Jones, P. D., and Pengqun, J.: The spatial response of the climate system to explosive volcanic eruptions, Int. J. Clim., 16, 537-550, 1996.

Kersting, A. B. and Arculus, R. J.: Pb isotope composition of the Klyuchevskoy volcano, Kamchatka and North Pacific sediments: Implications for magma genesis and crustal recycling in the Kamchatkan arc, Earth Planet. Sci. Lett., 136, 113-148, 1995.

Kuehn, S. C., Froese, D. G., and Shane, P. A. R.: INTAV Intercomparison Participants, The INTAV intercoparison of electron-beam microanalysis of glass by tephrochonology laboratories: Results and recommendations, Quaternary Int., 246, 19-47, 2011.

Kyle, P., Ponomareva, V. V., and Schluep, R.R.: Geochemical characterization of marker tephra layers from major Holocene eruptions, Kamchatka Peninsula, Russia, Int. Geol. Rev., 53, 10591097, 2011.

Lacasse, C. and Garbe-Schonberg, C. D.: Explosive silicic volcanism in Iceland and the Jan mayen area during the last 6Ma: Sources and timing of major eruptions, J. Volcan. Geoth. Res., 107, 113-147, 2001

Lamb, H. H.: Volcanic Dust in the Atmosphere, Philos. Trans. Roy. Soc. London, A266, 426-533, 1970.

Langway Jr., C. C., Clausen, H. B., and Hammer, C. U.: An interhemispheric volcanic time-marker in ice cores from Greenland and Antarctica, Ann. Glaciol., 10, 102-108, 1988.

Lanphere, M., Champion, D., Melluso, L., Morra, V., Perrotta, A., Scarpati, C., Tedesco, D., and Calvert, A.: Ar-40/Ar-39 ages of the AD 79 eruption of Vesuvius, Italy, Bull. Volc., 69, 259-263, doi:10.1007/s00445-006-0071-8, 2007.

Le Maitre, R. W., Bateman, P., Dudek, A., Keller, J., Lameyre Le Bas, M. J., Sabine, P. A.,Schmid, R., Sorensen, H., Streckeisen,
A., Woolley, A. R., and Zanettin, B.: A Classificationof Igneous Rocks and Glossary of Terms, Blackwell, Oxford, 193 pp., 1989.

Lerbekmo, J. F. and Campbell, F. A.: Distribution, composition, and source of the White River ash, Yukon Territory, Can. J. Earth Sci., 6, 109-116, 1969.

Lowe, D. J.: Tephrochonology and its application: a review, Quaternary Geochron., 6, 107-153, 2011.

Machida, H. and Arai, F.: Extensive ash falls in and around the sea of Japan from large late quaternary eruptions, J. Volcan. Geoth. Res., 18, 151-164, 1983.

Macias, J. L., Espindola, J. M., Garcia-Palomo, A., Scott, K. M., Hughes, S., and Mora, J. C.: Late Holocene Pelean-style eruption at Tacana volcano, Mexico and Guatemala: past, present, and future hazards, Geol. Soc. Am. Bull., 112, 1234-1249, 2000.

Marianelli, P. and Sbrana, A.: Risultati di misure di standard di minerali e di vetri naturali in microanalisi a dispersione di energia (in Italian), Atti Soc Tosc. Sci. Nat., Mem., Serie A, 105, 57-63, 1998.

Narcisi, B., Petit, J. R., and Delmonte, B.: Extended East Antarctic ice-core tephrostratigraphy, Quaternary Sci. Rev., 29, 21-27, 2010.

Newhall, C. G. and Self, S.: The volcanic explosivity index (VEI): an estimate of explosive magnitude for historical volcanism, J. Geophys. Res. Ocean. Atmos., 87, 1231-1238, 1982.

Nielsen, C. H. and Sigurdsson, H.: Quantitative methods for electron microscope analysis of sodium in natural and syntetic glasses, Am. Min., 66, 547-552, 1981.

Palais, J. M., Kirchner, S., and Delmas, R. J.: Identification of some global volcanic horizons by major element analysis of fine ash in Antarctic ice, Ann. Glaciol., 14, 216-220, 1990.

Rampino, M. R. and Self, S.: Historic eruptions of Tambora (1815), Krakatau (1883), and Agung (1963), their stratospheric aerosols, and climatic impact, Quaternary Res., 18, 127-143, 1982.

Rasmussen, S. O., Andersen, K. K., Svensson, A., Steffensen, J. P., Vinther, B. M., Clausen, H. B., Siggaard-Andersen, M. L., Johnsen, S. J., Larsen, L. B., Dahl-Jensen, D., Bigler, M., Röthlisberger, R., Fischer, H., Goto-Azuma, K., Hansson, M. E., and Ruth, U.: A new Greenland ice core chronology for the last glacial termination, J. Geophys. Res., 111, D06102, doi:10.1029/2005JD006079, 2006.

Robin, C., Eissen, J. P., and Monzier, M.: Giant tuff cone and 12km-wide associated caldera at Ambrym volcano (Vanuatu, New Hebrides Arc), J. Volcan. Geotherm. Res., 55, 225-238, 1993.

Robin, C., Smaniego, P., Le Pennec, J.-L., Mothes, P., and van der Plicht, J.: Late Holocene phases of dome growth and Plinian activity at Guagua Pichincha volcano (Ecuador), J. Volcan. Geotherm. Res., 176, 7-15, 2008.

Santacroce, R., Cioni, R., Marianelli, P., Sbrana, A., Sulpizio, R., Zanchetta, G., Donahue, D. J., and Joron, J. L.: Age and whole rock-glass compositions of proximal pyroclastics from the major explosive eruptions of Somma-Vesiuvius: A review as a tool for distal tephrostratigraphy, J. Volcan. Geotherm. Res., 177, 1-18, 2008.

Shane, P. and Wright, I. C.: Late Quaternary tephra layers around Raoul and Macauly island, Kermadec Arc: implications for volcanic sources, explosive volcanism and tephrochronology, J. Quaternary Sci., 26, 422-432, 2011.

Sheridan, M. F., Barberi, F., Rosi, M., and Santacroce, R.: A model of Plinian eruptions of Vesuvius, Nature, 289, 282-285, 1981. 
Sigurdsson, H., Carey, S., Cornell, W., and Pescatore, T.: The eruption of Vesuvius in 79 AD, Nat. Geograph. Res., 1, 1-37, 1985.

Sigurdsson, H., Cornell, W., and Carey, S.: Influence of magma withdrawal on compositional gradients during the AD 79 Vesuvius eruption, Nature, 345, 519-521, 1990.

Soden, B. J., Wetherald, R. T., Stenchikov, G. L., and Robock, A.: Global cooling after the eruption of Mount Pinatubo: A test of climate feedback by water vapor, Science, 296, 727-730, 2002.

Steffensen, J. P.: The size distribution of microparticles from selected segments of the Greenland Ice Core Project ice core representing different climatic periods, J. Geophys. Res., 102. 2675526763, 1997.

Stothers, R. B.: The great Tampora eruption in 1815 and its aftermath, Science, 224, 1191-1198, 1984.

Stothers, R. B. and Rampino, M. R.: Volcanic eruptions in the Mediterranean before A.D.630 from written and archaeological sources, J. Geophys. Res, 88, 6357-6371, 1983.

Svensson, A., Andersen, K. K., Bigler, M., Clausen, H. B., DahlJensen, D., Davies, S. M., Johnsen, S. J., Muscheler, R., Parrenin, F., Rasmussen, S. O., Röthlisberger, R., Seierstad, I., Steffensen, J. P., and Vinther, B. M.: A 60000 year Greenland stratigraphic ice core chronology, Clim. Past, 4, 47-57, doi:10.5194/cp-4-472008, 2008.

Taylor, K. C., Alley, R. B., Lamorey, G. W., and Mayewski, P.: Electical measurments on the Greenland Ice Sheet Project 2 core, J. Geophys. Res., 102, 26511-26517, 1997.

Vinther, B. M., Clausen, H. B., Johnsen, S. J., Rasmussen, S. O., Andersen, K. K., Buchardt, S. L., Dahl-Jensen, D., Seierstad, I. K., Siggaard-Andersen, M.-L., Steffensen, J. P., Svensson, A., Olsen, J., and Heinemeier, J.: A synchronized dating of three Greenland ice cores throughout the Holocene, J. Geophys. Res., 111, D13102, doi:10.1029/2005JD006921, 2006.
Westercamp, D. and Traineau, H.: The past 5000 years of volcanic activity at Mt. Peleé, Martinique (F.W.I.): Implications for assessement of volcanic hazards, J. Volcanol. Geotherm. Res., 17, 159-185, 1983.

Wolff, J. A. and Storey, M.: The volatile component of some pumice-forming alkaline magmas from the Azores and Canary Islands, Contrib. Mineral. Petrol., 82, 66-74, 1983.

Zielinski, G. A.: Stratospheric loading and optical depth estimates of explosive volcanism over the last 2100 years derived from the Greenland Ice Sheet Project 2 ice core, J. Geophys. Res., 100, 20937-20955, 1995.

Zielinski, G. A. and Germani, M. S.: New Ice-Core Evidence Challenges the 1620s BC age for the Santorini (Minoan) Eruption, J. Archaeolog. Sci., 25, 279-289, 1998.

Zielinski, G. A., Mayewski, P. A., Meeker, L. D., Whitlow, S., Twickler, M. S., Morrison, M., Meese, D., Alley, R. B., and Gow, A. J.: Record ofvolcanism since 7000 B.C. fromteh GISP2 Greenland ice core and implications for the volcano-climate system, Science, 264, 984-952, 1994.

Zielinski, G. A., Mayewski, P. A., Meeker, L. D., Whitlow, S., and Twickler, M. S.: A 110,000 year record of explosive volcanism from the GISP 2 (Greenland) ice core, Quaternary Res., 45, 109118, 1996. 